\title{
Severe staphylococcal marginal keratitis presenting with hypopyon
}

\author{
Jeremy Hoffman, Ali Hassan
}

Department of Ophthalmology, Surrey and Sussex Healthcare NHS Trust, Redhill, UK

\section{Correspondence to} Dr Jeremy Hoffman, jeremy.hoffman@nhs.net

Accepted 5 August 2015
CrossMark

To cite: Hoffman J, Hassan A. BMJ Case Rep Published online: [please include Day Month Year] doi:10.1136/bcr-2015211979

\section{DESCRIPTION}

An 83-year-old woman presented with a red right eye with associated visual loss. She described grittiness, denying significant pain. Symptoms had progressed over several months, on a 2-year history of epiphora and 'irritable' eyes.

Visual acuity was perception of light in the right eye. Examination demonstrated severe blepharitis and significant conjunctival injection. Two large peripheral corneal epithelial defects with stromal infiltration were present together with a $4.5 \mathrm{~mm}$ hypopyon (figure 1A, B). The left eye showed two round, discrete, peripheral ulcerative lesions with subepithelial infiltrates. No view of the posterior segment of the right eye was possible due to the hypopyon. B-scan ultrasonography demonstrated a clear vitreous and flat retina, with no evidence of endophthalmitis (figure 1C). Fundus examination of the left eye was unremarkable.

The patient was diagnosed with severe marginal keratitis (MK), admitted and started on hourly preservative-free levofloxacin eye drops $(5 \mathrm{mg} / \mathrm{mL})$ for $48 \mathrm{~h}$ and subsequently started on two-hourly preservative-free dexamethasone eye drops $(1 \mathrm{mg} / \mathrm{mL})$ with the levofloxacin reduced to four times daily. Corneal scrapings for microscopy and culture yielded no microbial growth.

One week following the start of steroids the conjunctival injection and hypopyon had resolved (figure 2). Vision improved to 6/36. The patient was discharged on a topical dexamethasone regime.

Staphylococcal MK is an immune-mediated response to bacterial antigens present with lid margin disease, typically presenting with peripheral corneal infiltrates with overlying epithelial loss adjacent to the limbus; staphylococcal MK stains with fluorescein, separated by an interval of clear cornea. $^{1}{ }^{2}$ The ulcers may be round or arcuate,

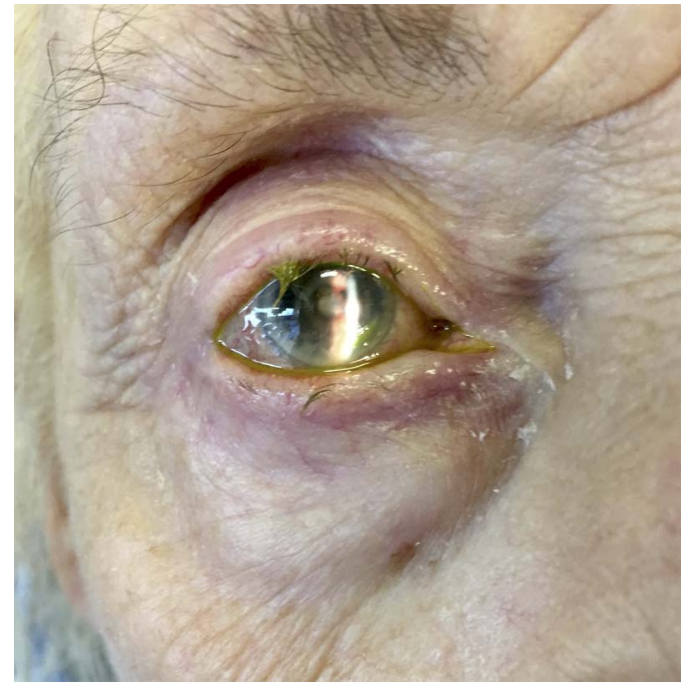

Figure 2 One week following the start of steroids, the eye was white and the hypopyon had resolved. Vision improved to 6/36. There was evidence of chronic anterior uveitis in the form of dilated iris vessels, posterior synechiae and iris atrophy. A nuclear sclerotic cataract was also present.

single or multiple, unilateral or bilateral. Treatment is with a combination of topical antibiotics and steroids. Anterior chamber inflammation is rare. ${ }^{3}$

Endophthalmitis is an important differential in a case presenting with a red, painful eye and hypopyon, such as that seen in figure $1 \mathrm{~A}$. Owing to its sight-threatening nature, it needs to be excluded carefully. Causes and risk factors are described below (table 1). ${ }^{4}$ There were no risk factors for endophthalmitis in our patient; this, together with the preceding chronic history, total lack of pain and normal B-scan ultrasonography, made endophthalmitis very unlikely.

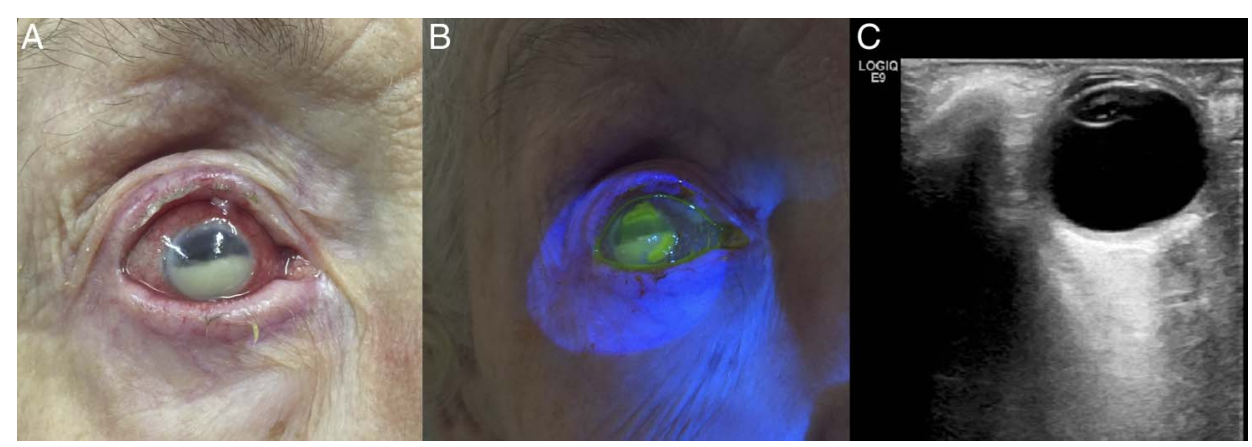

Figure 1 (A) Two large peripheral marginal corneal epithelial defects with subepithelial stromal infiltration were present measuring approximately 4.5 and $4.0 \mathrm{~mm}$ in length, between 10 and $2 \mathrm{o}^{\prime}$ clock and 3 and 9 o'clock, respectively, $1.5 \mathrm{~mm}$ from the limbus. A $4.5 \mathrm{~mm}$ hypopyon was present. (B) The marginal epithelial defects staining brightly with fluorescein sodium 1\% eye drops under cobalt blue filter. (C) B-scan ultrasound image of the right eye showing no evidence of endophthalmitis. 
Table 1 Types of endophthalmitis, causative organisms and risk factors ${ }^{4}$

\begin{tabular}{|c|c|c|}
\hline Type of endophthalmitis & Most common organisms & Risk factor(s) \\
\hline Acute post-cataract & $\begin{array}{l}\text { Coagulase-negative staphylococci ( } 70 \% \text { of cases), other Gram-positive } \\
\text { cocci }(25 \%)\end{array}$ & $\begin{array}{l}\text { Complicated surgery (vitreous loss, prolonged procedure) } \\
\text { Periocular infection (eyelid, lacrimal) } \\
\text { Diabetes mellitus }\end{array}$ \\
\hline Chronic post-cataract & Propionibacterium acnes & $\begin{array}{l}\text { Complicated surgery (vitreous loss, prolonged procedure) } \\
\text { Periocular infection (eyelid, lacrimal) } \\
\text { Diabetes mellitus }\end{array}$ \\
\hline Post-intravitreal injection & Coagulase-negative staphylococci, viridans streptococci & $\begin{array}{l}\text { Contaminated equipment } \\
\text { Allergy to povidone iodine }\end{array}$ \\
\hline Bleb related & Streptococci, Haemophilus influenzae & Thin walled leaking bleb \\
\hline Post-traumatic & Bacillus cereus, coagulase-negative staphylococci (fungi in some cases) & $\begin{array}{l}\text { Penetrating trauma } \\
\text { Organic matter } \\
\text { Intraocular foreign body }\end{array}$ \\
\hline Endogenous bacterial & Staphylococcus aureus, streptococci, Gram-negative bacilli (eg, Klebsiella) & $\begin{array}{l}\text { Endocarditis } \\
\text { Indwelling central venous catheters } \\
\text { Illicit intravenous drug use } \\
\text { Hepatobiliary sepsis } \\
\text { Interventional procedures causing transient } \\
\text { bacteraemia }\end{array}$ \\
\hline $\begin{array}{l}\text { Candida (mostly } \\
\text { endogenous) }\end{array}$ & Candida spp & $\begin{array}{l}\text { Indwelling central venous catheter } \\
\text { Total parenteral nutrition } \\
\text { Broad-spectrum antibiotics } \\
\text { Recent abdominal surgery }\end{array}$ \\
\hline Mould (mostly exogenous) & Aspergillus, Fusarium & $\begin{array}{l}\text { Intraocular surgery } \\
\text { Trauma } \\
\text { Keratomycosis }\end{array}$ \\
\hline
\end{tabular}

This case highlights that, if neglected, significant intraocular inflammation can develop, resulting in a large hypopyon. A thorough history and comprehensive bilateral ocular examination, supplemented by B-scan ultrasonography, can help to rule-out endophthalmitis, thereby avoiding unnecessary invasive intravitreal or anterior chamber sampling. Response to antibiotic

\section{Learning points}

- Marginal keratitis is a common cause of a red, uncomfortable eye, often presenting bilaterally with peripheral, discrete infiltration with circum-limbal sparing.

- It is non-infectious and results from an enhanced cell-mediated immunity, at the limbus, to antigens of Staphylococcus aureus on the lids; treatment is therefore with a combination of topical antibiotics and steroids, and usually results in a rapid resolution of signs and symptoms.

- Although unusual, in severe cases, a hypopyon may develop and potentially cause diagnostic confusion; in this scenario, a detailed history and examination to exclude risk factors for endophthalmitis are required. and steroid therapy is usually rapid; failure to respond should prompt investigation for alternative causes of peripheral corneal ulceration.

Twitter Follow Jeremy Hoffman at @idoctorhoff

Acknowledgements The authors would like to acknowledge consultant ophthalmologist Miss Lucia Pelosini for her help in managing the patient, as well as the nursing and auxiliary staff at East Surrey Hospital.

Contributors $\mathrm{JH}$ treated the patient, obtained photographs and consent, and wrote the manuscript. AH treated the patient, and reviewed and modified the manuscript.

Competing interests None declared.

Patient consent Obtained.

Provenance and peer review Not commissioned; externally peer reviewed.

\section{REFERENCES}

1 Ficker L, Seal D, Wright P. Staphylococcal infection and the limbus: study of the cell-mediated immune response. Eye (London) 1989;3:190-3.

2 Srinivasan M, Mascarenhas J, Prashanth C. Distinguishing infective versus noninfective keratitis. Indian J Ophthalmol 2008;56:203-7.

3 Boto-de-Los-Bueis A, Del Hierro Zarzuelo A, García Perea A, et al. Staphylococcus aureus Blepharitis Associated with Multiple Corneal Stromal Microabscess, Stromal Edema, and Uveitis. Ocul Immunol Inflamm 2015:23:180-3.

4 Durand ML. Endophthalmitis. Clin Microbiol Infect 2013;19:227-34.

Copyright 2015 BMJ Publishing Group. All rights reserved. For permission to reuse any of this content visit

http://group.bmj.com/group/rights-licensing/permissions.

BMJ Case Report Fellows may re-use this article for personal use and teaching without any further permission.

Become a Fellow of BMJ Case Reports today and you can:

- Submit as many cases as you like

- Enjoy fast sympathetic peer review and rapid publication of accepted articles

- Access all the published articles

- Re-use any of the published material for personal use and teaching without further permission

For information on Institutional Fellowships contact consortiasales@bmjgroup.com

Visit casereports.bmj.com for more articles like this and to become a Fellow 